\title{
Introduction: theorizing semi-peripheral geographies of finance and banking
}

\section{Christian Sellar, Silvia Grandi and Juvaria Jafri}

\section{BEYOND CORE-CENTERED FINANCIAL GEOGRAPHIES}

This edited collection explores the boundaries between political and financial geographies: it interrogates linkages between the changing spatialities and policies of the state, the evolution of a globalizing financial system, and the consequences of this for people and firms. Empirically, it focuses on the semi-periphery of the financial system to generate new perspectives on the entanglement between (geo)politics and finance: these complement and overlap with the core-centered analyses of what has come to be an Anglo-American geography of finance. Conceptually, it engages with insights from a variety of disciplines in order to explore the connections between geopolitical and geo-economic discourses, public finance and foreign policy, the practices and localization of financial institutions, and the evolution of strategies for globalizing firms. Such topics are becoming increasingly relevant, as evidenced in a speech by the UK Deputy Governor for Prudential Regulation in which the term 'geofinance' is presented as a dynamic to acknowledge the 'impact of geography on the shape of banks, insurers and financial regulation ... With the revolution in regulation following the financial crisis coming to its end, and with changes to the geopolitical landscape looming large'. He observed that geofinance will be 'the defining challenge of the next few years' (Woods 2017).

The chapters in this book explore trends, data, policies and geographies in Bulgaria, Brazil, Italy, Pakistan, Russia, Turkey and Vietnam. In addition, they offer cross-country analyses for Central and Eastern Europe, and examine the evolutionary patterns of international financial institutions and other supranational financial players. All this has resulted in a complex web of relationships between governments and actors in finance which has, in turn, had an impact on firms as well as households (Figure I.1). Taken together, these are under-represented locations in the geography of finance: the focus on these underpins the originality of this 


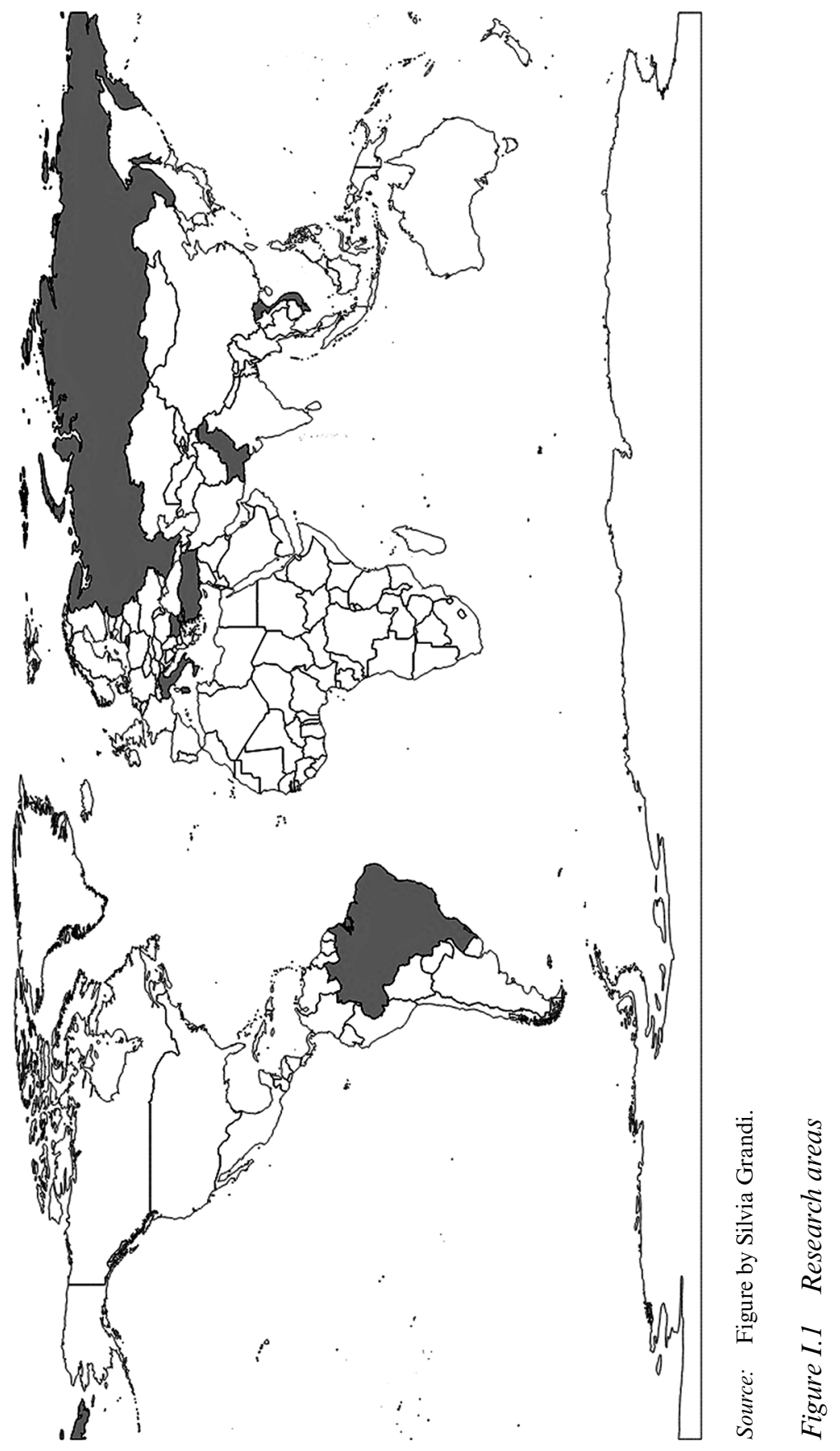


book. Recalling Wallerstein's original formulation of world-systems theory (Wallerstein 1974), but also older formulations such as Walter Christaller's central place theory (Christaller 1966; see also Lösch 1954), the spaces covered in this book are collectively defined as semi-peripheral financial areas. Wallerstein's (1974, p. 102) analysis of capitalism in early modern Europe described the semi-periphery as areas with relatively limited or declining access to international and high-quality banking services that engaged in the production of high-quality goods but nevertheless were subjugated to international trade or finance. More recently, Arrighi (2010) extended his reasoning to include finance more explicitly. Thus, building on their work, here, the notion of semi-peripheral financial areas refers to established industrial or emerging economies outside the financial centers of North America, north-western Europe and East Asia, where financial industries are established but do not have the same level of global influence as the core. Our view is that the latter point distinguishes the cases discussed in this book from more commonly used notions such as fringes, edges or margins, and in particular from research that takes as its central concern the lack of established traditional financial sectors, and sometimes reverse innovation and new forms of finance (Govindarajan and Trimble 2012; Klagge and Zademach 2018; Yunus 2009). Taken together, the chapters in this book portray economies with well rooted 'bricks and mortar' financial institutions, and a clearly discernible - whether explicit or implicit - role of the state in creating financial flows and supporting the financing of firm and household activity.

\section{SPEAKING FROM THE SEMI-PERIPHERY}

This book's engagement with the semi-periphery is rooted in our reflexive positions as editors: this frames our own engagement with the authors, and with the larger field of financial geography. We are two women, one man; two immigrants, one working in her own country of origin; two working within the boundaries of Anglo-American academia, and one outside. Ethically, we felt a duty to facilitate the inclusion of a wider range of scholars in the mainstream debates of the discipline. Conceptually, three issues attracted our attention. First, and unsurprisingly, a survey of financial geography we did in early 2018 (Clark and Wójcik 2007; Dixon and Monk 2014; Elson 2011; Grote et al. 2017; Wójcik et al. 2017), including working papers published by the Global Network on Financial Geography (FinGeo 2019) revealed analyses firmly placed within economic geography. Since then, a few papers have begun investigating the geopolitical dimensions of banking and finance (Aalbers 2018; Bassens 
and Van Meeteren 2018; Karwowski and Centurion-Vicencio 2018), but there is still some inattention to the ways in which state geo-economic strategies may shape the financial sector, and vice versa. Second, while our Italian colleagues were keen to study the role of banking and finance in shaping the internationalization of small and medium-sized enterprises, Anglo-American geography seemed less interested in exploring the links between manufacturing value chains and international finance. Third, and surprisingly, the majority of papers on financial geographies we read by the beginning of our collaboration in summer 2017 had a distinctive spatial bias. Methodologically, they were based either on data about large global players such as sovereign wealth funds or transnational consulting and accounting firms (Dixon and Monk 2014; Dörry 2018), or on empirical research collected in or around the core of the global financial system in the UK (Pažitka and Wójcik 2017) and the US (Wójcik and Cojoianu 2017), as well as the emerging financial centers of China (Pan et al. 2018). A smaller number of researchers focused on the fringes of the financial system (Klagge and Zademach 2018; Roy 2010), but intermediate areas, with established but non-dominant financial institutions, seemed to be missing. This bias seemed to be specific to geography, because several works in heterodox finance had a focus on the semi-periphery (Braun et al. 2018). We thus observed an empirical research deficit in geography that obscured several perspectives, including those on economies outside the financial core, as well as those of players that are not the best-known global investment, insurance and consulting firms.

Building on these earlier intuitions, our call for chapters had two objectives. The first was conceptual: we wanted to present a book about globalizing finance and banks that spoke directly to debates in geopolitics and political geography. We particularly wanted to insert banks and finance within larger geostrategic processes affecting the spatiality of the nation state. For this, we sought to show the links between the political geographies of the state and more conventional economic geography themes, placing finance in the context of politics and firms and household behavior. The second goal was to broaden the empirical reach of financial geographies by disseminating our call to draw in scholars writing about finance outside the financial centers of the US, the UK, Western Europe and East Asia. Our own situational perspective, especially given our connections with Italy, where there is a strong tradition of commercial diplomacy via state-owned financial instruments (Vergara Caffarelli and Veronese 2018), framed the two hypotheses connecting the two goals. These hypotheses are (1) there is a variety of relationships between statelevel geo-economic and development strategies, the institutions and goals of the financial sector, and the credit available to firms and households, 
and (2) such relations are more readily visible outside the US and the UK, where long-standing classical liberal and neoliberal traditions tend to limit government involvement in bank lending decisions.

\section{CONTRIBUTOR-DRIVEN THEORIZATION}

To accomplish the above goals, we cast the call for papers as widely as possible, stating that foci of the book were the "various public and private aspects of banking that shape geopolitical trends and vice versa' with the goal of 'exploring the links between state geo-economic strategies, financial institutions and firm internationalization'. As a result, we collected a variety of papers (hereafter chapters) discussing under-represented geographies of finance, as shown in Figure I.1, that create what we named semi-peripheral financial areas: this is a belt between core financial countries and emerging and developing countries where, in general, the struggle between state-bank relationships is unresolved, innovation lags financial processes and banking policies are not always centered on firm and household needs.

The authors of these chapters represent a wide array of disciplines, career stages, and training, only some of which is rooted in Anglo-American academia. To help facilitate authors trained outside this tradition, Juvaria Jafri joined the editorial team to edit submissions. This entailed a discussion within the expanded editorial team about how to incorporate a wide array of criteria of what constitutes good scholarship in ways that could be meaningful to a wider international audience. Indeed, geographers have long questioned the extent to which the knowledge they produce is truly international (Gutierrez and Lopez-Nieva 2001; Kitchin 2003; Rodríguez-Pose 2004, 2006). The first, and obvious, critique has been that the international geographical journals are British and American, and foreign scholars rarely get published unless they hold $\mathrm{PhDs}$ from universities in the US or UK (Aalbers 2004; Aalbers and Rossi 2007). Theoretical pieces that build upon non-Anglo-American scholarly traditions are rarely accepted (Minca 2000). Responding to this critique, several journal special issues have focused on the need to open up international human geography to the contributions of non-English speaking scholars and traditions (Environment and Planning 2003; Berg 2004; European Urban and Regional Studies 2004).

The critical issue that runs across such scholarship is the expectation that theory is produced by scholars working in a narrow band of elite Anglo-American - universities, while the rest of us can at best provide empirical evidence. On the one hand, we are keenly aware that theory that 
is appreciated by the wider scholarly community is produced according to highly specific codes and is usually restricted to a handful of universities. On the other hand, such codes can potentially obscure variant interpretations of data and, more generally, impede scholarship from those trained outside the core. So, in order to be as inclusive as possible, we sought to strike a balance between contributions written by scholars and practitioners, as well as those from scholars trained and working within AngloAmerican academia versus those trained in the countries under scrutiny. This variety in academic standards and styles allowed for the collection of multiple disciplinary perspectives, including geography, business, regional development, political science and economics.

After collecting the chapters, we engaged in contributor-driven theorization: we let the authors interpret our call and produce chapters on their own terms, and we limited our editing to ensuring that the chapters are clearly written and understandable to an international audience. After collecting the chapters, we identified recurrent themes: first, a macro-level perspective on the global institutions that drive banking and finance; second, an attention to how state policies affects banks; and third, several discussions of how banks' and other financial institutions' choices reflect in lending practices. Finally, we tied these foci together in a theoretically meaningful argument. To do this, first we linked political geography - especially works on the changing spatialities of the state - with finance. Second, we emphasized the role of banks as a site for bridging state policies with the larger world of finance. As a result, we developed the notion of geofinance/banking. This concept signals that banks and other lending institutions play a key and under-explored role in connecting policies of the state in the semi-periphery with globalizing trends originating in the financial core: these are articulated through flows of financial resources and their distribution in specific sub-national and national settings.

\section{ORGANIZATION OF THE BOOK}

The remainder of the book commences with a chapter that introduces the notion of geofinance/banking. Subsequent chapters are grouped in three parts, roughly corresponding to three scalar levels: the global and supranational, the national and the micro levels. The first part carries those contributions that engage with the spatial structures of banking. The second part explores the policy-politics-banks-firms nexus with finance in the semi-peripheries. The third and final part highlights the micro-level dimension of people and firm responses. 
Chapter 1 is by the editorial team and links political geography with banking and finance through geofinance/banking. In so doing, we understand political geography as an umbrella term covering geopolitics as well as a wide array of perspectives on the spatialization of politics. We build on Sami Moisio's Geopolitics of the Knowledge-Based Economy (2018) as well as on Jones's (2016) work on new political geography. Moisio develops Çalışkan and Callon's (2009) notion of economization, understood as 'the material processes of knowledge-intensive capitalism ... and the processes whereby this form of capitalism is constructed discursively' (Moisio 2018, p. 1). His key claim is that economization includes a key geopolitical dimension, constituted by both the territorial power of states and the imagery of hubs, networks and flows that permeates the late capitalist economy. Economization connects firms and political communities (Moisio 2018, p. 16) and accounts for the reshuffling of territoriality (Moisio 2018, p. 19). Extending this argument to banking and finance, we argue that finance and its geographies constitute an under-explored but crucial factor linking the evolving - bounded and relational - territorialities of the nation-state to firms and citizens. To operationalize geofinance/ banking, we start from Jones's (2016, p. 2) conceptualization of political geography as a 'double triangle', the first triangle including power, politics and policy, and a second consisting of space, place and territory. To this we add three additional terms: financial flows (the flows and management of money and other financial tools), institutions (banks, international financial institutions and other actors) and client firms and households. We see the chapters in our edited collection as engaging with, albeit not exhaustively, the permutations of these nine concepts (Table I.1).

After the chapter on geofinance/banking, Part I starts with Silvia Grandi's analysis of the geographical patterns of the international financial institutions (IFIs) that tend to be marginalized in the mainstream finance literature, particularly in the context of the semi-peripheries (Chapter 2). These institutions have shaped global finance and the outlook and geography of the world banking system: they are thus key drivers of geobanking/ finance. The chapter shows patterns in the distribution of headquarters versus areas of investments, as well as the power relationships between boards and the rest of each organization. The chapter also discusses the uneven access to financial institutions, making the case that in the semiperiphery, private finance is oftern substituted for or supplemented by government funds obtained via IFIs. Chapter 2 thus shows the complexity of global financial institutions where power, policies, politics and finance can significantly shape places.

Also in Part I, Gianfranco Battisti explores the spatial and organizational boundaries of the financial system by discussing the articulation 


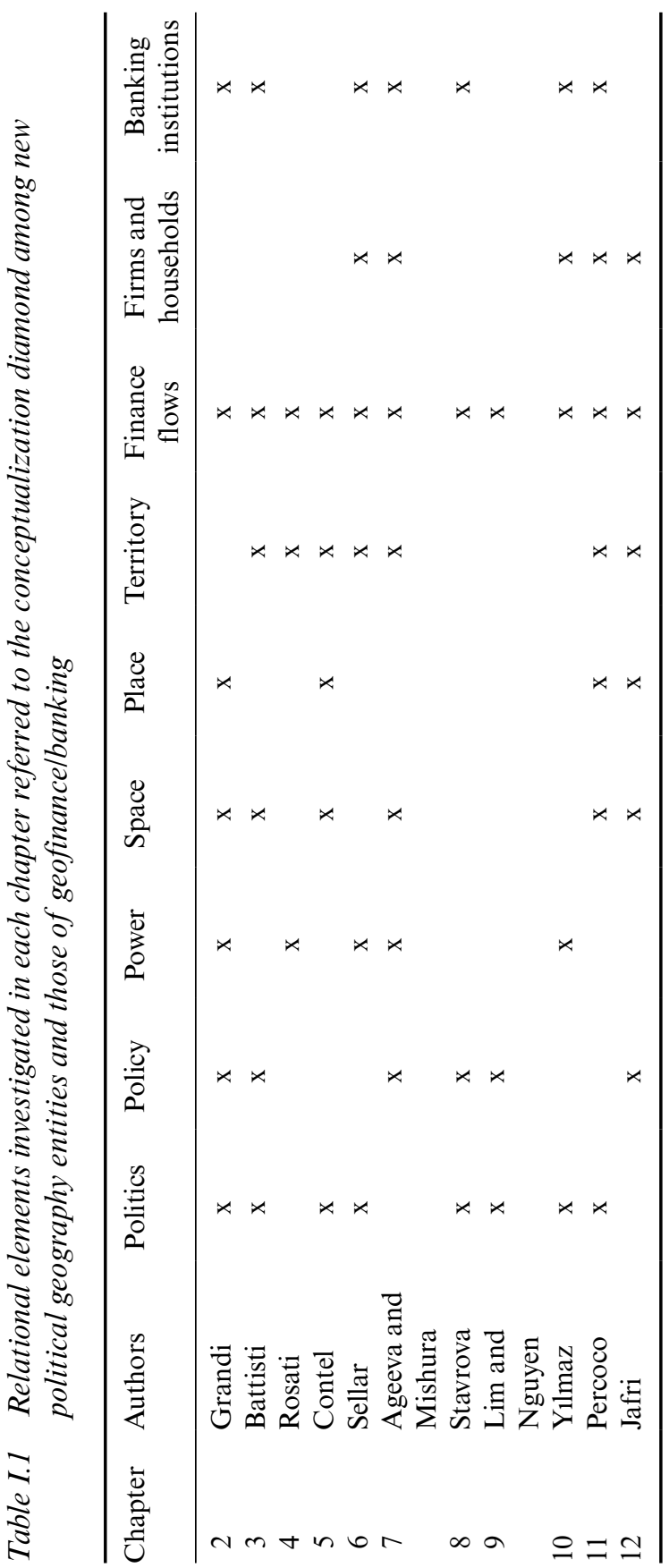


between shadow banking and the formal financial system (Chapter 3). In so doing, this chapter highlights the highly fragmented nature of shadow banking, noting that it does not constitute a system parallel to official banking and financial institutions; instead, shadow banks are a long-standing phenomenon traced back to the seventeenth century that is co-dependent and intertwined with its more regulated, official counterpart. The chapter explores the evolution of this entanglement around the global financial crisis of 2008. While regulators seemed taken by surprise by the importance of the sector and by the inadequacy of existing regulations to curb the crisis outside the boundary of official banking, insiders were aware of the relationships between banking and shadow banking. In particular, Battisti traces the growth of shadow banking in the years preceding the crisis in the decisions taken by official banking institutions to refocus their business, opening up market spaces to shadow - and thus less regulated - institutions. Shadow banking exists in a collaborative, but at the same time competitive, relationship with official finance and banking.

Umberto Rosati explores the financial centre perspective in classical models of the urban concentration of banks, stock markets, insurance and financial companies (Chapter 4) where two different economic forces - centrifugal and centripetal - operate within the financial space to define the spatial structure of the financial economy. In particular, Rosati's analysis notes that offshoring, seen here as a located in the semi-periphery, also plays a core role in shaping spaces, territories and local-global-local finance. Thus, offshore banking creates peculiar local systems where offshore places are located as well as clusters where this form of finance is spread.

A further form of spatiality is analyzed by Fabio Betioli Contel (Chapter 5) which relates to the urban effects of the Brazilian financial system. This is achieved through the identification of the main cities that behave similarly to financial centers. The study of financial centers is through frames that are historical and theoretical. This Brazilian case hence reveals the primacy of the city of São Paulo and the dispute over 'lower' functions by the cities of Brasilia and Rio de Janeiro in the national urban network creating national centers and sub national financial semi-peripheries.

Part II of the book explores the state-policy-politics-bank-firm nexus in the finance semi-peripheries and opens with the bank-business services relationship. Conceived thus, this is another form of the spatial structure of banking as well as a pathway for engagement with the state-bank-firm nexus in the finance semi-peripheries. Christian Sellar addresses this topic in a study of Italian banks and business services as well as their relationships to small and medium-sized enterprise (SME) outsourcing in Central and Eastern Europe (Chapter 6). The relationship between the 
internationalization of banks, services and SMEs as banks and services enables resource mobilization in the form of knowledge pipelines between Italian firms and Central and Eastern European regional economies.

The policy-bank-firm relationship, especially for SMEs, is also addressed by Svetlana Ageeva and Anna Mishura (Chapter 7) who analyze the role of the Russian banking system in the allocation of financial resources across regions where, over the past two decades, the number of Russian banks has declined. The geobanking phenomenon here is a repolarization to the capital and an increasingly Moscow-centered and state-orientated banking system. This has been to the detriment of privately owned smaller and regional banks, resulting in precarious access to credit for peripheral SMEs. Large network banks, headquartered mainly in Moscow, provide regular flows of financial resources concentrated in the capital for the lending needs of other regions. However, according to the Ageeva and Mishua study, the 'flight to home' and 'flight to quality' effects during the crisis period after 2014 show that, despite a significant state-based policy intervention, lending to SMEs and new enterprises remains very vulnerable, and is still largely dependent on government support programs and on central bank requirements for SME-orientated banks.

Elena Stavrova presents a historical account of the development of the banking system in Bulgaria where the economy transitioned from being command administered to market based. She thus analyzes the transformational patterns of national policy, foreign investment and the involvement of international financial institutions given the relatively sudden privatization of banks (Chapter 8). This 30 -year process entailed a complex mix of policies that led to cycles of stability, but also crises, inflation and the proliferation, fragmentation and concentration of a banking system which includes state-controlled and foreign banks. Stavrova's study is thus one of geobanking development in the former satellite countries of the Soviet Union and offers an archetypal perspective on the complexity of transitions to a private system.

The role of the state is also a focal point for Guanie Lim and Thong Tien Nguyen who study the doi moi (renovation) reforms in Vietnam in the late 1980s. Through this, they explore the power-policy-banking-firm nexus in an Asian transition economy and a fast-moving semi-periphery financial area (Chapter 9). The membership of the Association of Southeast Asian Nations (ASEAN) and the accession in 2007 to the World Trade Organization (WTO) have unlocked new export markets for Vietnamese firms and integrated them, albeit unevenly, in global value chains. However, this story is more nuanced than that of a push towards neoliberalism, and the authors argue that a closer examination of the Vietnamese banking industry reveals that state-owned firms and banks are still subject to 
substantial direct or indirect political control. This moderates the effects of foreign capital on socio-economic structures and preserves power and capital structures in the banking system.

The contributions gathered in Part III share a concern for the microlevel dimension, the actions of financial institutions. Lending practices are a common thread in all three chapters of this part, and they offer a context for many of the opportunities and risks that shape places and territory. Part III opens with the chapter by Engin Y1lmaz investigating the practice adopted by Turkish banks of cross-currency swap as driving an unwieldy expansion of credit (Chapter 10). The growth of the Turkish economy and the enlargement of household wealth underlie a political consensus that is debt driven and the basis for economic vulnerability given potential financial crisis. The liaison between politics-policy-banking and household growth in Turkey highlights the complex and subtle risks associated with loan creation from a cross-currency swap mechanism. It is a commentary on how the overuse of derivatives reflects an unsustainable system in which the expansion of local loans has surpassed the local deposit base of Turkish banks, and where non-core and foreign currency liabilities (dollarization) plug this gap in the banking system.

Marco Percoco adds to the discourse on financial crises with a spatial, Schumpeterian and Marshallian perspective on the Italian cases of crises that affected four major local commercial banks in Italy (Chapter 11). Commonalities shared by these banks are that they have a sub-regional spatial concentration of branches, and they were reliant on the local economy to lend to local firms which are often SMEs active in exportorientated industrial clusters. Percoco argues that the reasons for these four banks facing crises should not be sought simply in the context of the financial investment made, but also elsewhere. One of these reasons is the exposure to international trade shocks faced by sectors directly tied to local industrial clusters and thus to firms. The second reason which Percoco draws attention to is particularly interesting as it highlights the importance for research in geobanking, and on the role, composition and strategies of corporate governance bodies, banks and the local ties of their personnel. Percoco argues that local social networks can limit information costs in credit score evaluation and thus address the problem of asymmetric information. Nevertheless, there is a 'dark side' where social pressures from local powers push biased credit choices and financial imbalances, and eventually result in the need for bail-outs. The effects are thus felt not only by the banks themselves, but also by firms, local households and national policies.

The final chapter pertains to the alternative banking approaches of microfinance and digital financial services; thus addressing financial 
activities of individuals and households who occupy the grey area between formality and informality (Chapter 12). By engaging with the notion of shadow banking and relating it to financial citizenship - described as the right and ability of individuals and households to participate fully in the economy and to accumulate wealth - Juvaria Jafri discusses issues of geobanking evolution and financial inclusion and exclusion in Pakistan. The configuration of financial inclusion and exclusion as opposite and mutually exclusive concepts is thus interrogated, and this reveals a fundamental contradiction of inclusive finance: the tendency to promote economic dualism by bifurcating the financial sector. Bifurcation creates an inferior form of inclusion and access to finance, but is nevertheless a crucial development policy tool in the Global South, drawing countries to the frontiers of semi-periphery finance areas. The proposition of connecting with global circuits of financial capital has underpinned the success of inclusive finance programs. The Pakistan case shows how inclusive finance has become increasingly commercial and digitally orientated, while being heavily regulated. These features make it particularly attractive for global capital which is often in the form of development assistance or private funds. The concept of shadow financial citizenship is a tool to critique the inclusive finance paradigm in the light of the financialization of development, which departs from traditional and formal mainstream banking practices to create an uneven, bifurcated form of development.

\section{REFERENCES}

Aalbers, M.B. (2004), 'Creative destruction through the Anglo-American hegemony: a non-Anglo-American view on publications, referees and language', Area, 36 (3) 319-22.

Aalbers, M.B. (2018), 'Financial geography I: geographies of tax', Progress in Human Geography, 42 (6), 916-27.

Aalbers, M.B. and Rossi, U. (2007), 'A coming community: young geographers coping with multi-tier spaces of academic publishing across Europe', Social \& Cultural Geography, 8 (2), 283-302.

Arrighi, G. (2010), The Long Twentieth Century. Money, Power and the Origins of our Times, London and New York: Verso.

Bassens, D. and Van Meeteren, M. (2018), 'Geographies of finance in a globalizing world', in R.C. Kloosterman, V. Mamadouh and P. Terhorst (eds), Handbook on the Geographies of Globalization, Cheltenham, UK and Northampton, MA, USA: Edward Elgar, pp. 248-57.

Berg, L. (2004), 'The spaces of critical geography', Geoforum, 35 (special issue), 523-58.

Braun, B., Gabor, D. and Hübner, M. (2018), 'Governing through financial markets: towards a critical political economy of Capital Markets Union', Competition \& Change, 22 (2), 101-16. 
Çalışkan, K. and Callon, M. (2009), 'Economization, part 1: shifting attention from the economy towards processes of economization', Economy and Society, 38 (3), 369-98.

Christaller, W. (1966), Central Places in Southern Germany, Englewood Cliffs, NJ: Prentice Hall.

Clark, G.L. and Wójcik, D. (2007), The Geography of Finance: Corporate Governance in the Global Marketplace, Oxford: Oxford University Press.

Dixon, A.D. and Monk, A. (2014), 'Frontier finance', Annals of the Association of American Geographers, 104 (4), 852-68.

Dörry, S. (2018), 'Creating institutional power in financialised economies: the firm-profession nexus of advanced business services', FinGeo Working Paper No. 12, March, Global Network on Financial Geography, Oxford University.

Elson, A. (2011), Governing Global Finance: The Evolution and Reform of the International Financial Architecture, New York: Palgrave Macmillan.

Environment and Planning (2003), 'Guest editorials', Environment and Planning D: Society and Space, 21 (special issue), 131-68.

European Urban and Regional Studies (2004), 'Euro commentaries themed section', European Urban and Regional Studies, 11 (special issue), 335-81.

Global Network on Financial Geography (FinGeo) (2019), Working papers, Global Network on Financial Geography, Oxford University, accessed 9 February 2019 at http://www.fingeo.net/fingeo-working-paper-series/.

Govindarajan, V. and Trimble, C. (2012), Reverse Innovation: Create Far from Home, Win Everywhere, Brighton, MA: Harvard Business Press.

Grote, M., Zook, H.M. and Heidorn, T. (2017), 'Geographical limits to arbitrage in the global oil market', FinGeo Working Paper No. 7, August, Global Network on Financial Geography, Oxford University.

Gutierrez, J. and Lopez-Nieva, P. (2001), 'Are international journals of human geography really international?', Progress in Human Geography, 25 (1), 53-69.

Jones, M. (2016), 'Polymorphic political geographies', Territory, Politics, Governance, $4(1), 1-7$.

Karwowski, E. and Centurion-Vicencio, M. (2018), 'Financialising the state: recent developments in fiscal and monetary policy', FinGeo Working Paper No. 11, February, Global Network on Financial Geography, Oxford University.

Kitchin, R. (2003), 'Cuestionando y desetabilizando la hegemonia angloamericana y del ingles en geografia' ('Questioning and de-stabilizing the Anglo-American hegemony of English language in geography'), Documents d'Analisi Geografica, 42, 17-36.

Klagge, B. and Zademach, H.-M. (2018), 'International capital flows, stock markets, and uneven development: the case of sub-Saharan Africa and the Sustainable Stock Exchanges Initiative (SSEI)', Zeitschrift Für Wirtschaftsgeographie, 62 (2), 92-107.

Lösch, A. (1954), The Economics of Location, New Haven, CT and London: Yale University Press.

Minca, C. (2000), 'Venetian geographical praxis', Environment and Planning D: Society and Space, 18 (3), 285-9.

Moisio, S. (2018), Geopolitics of the Knowledge-Based Economy, London: Routledge.

Pan, F., Hall, S. and Zhang, H. (2018), 'The geographies of financial activities within an emerging international financial center: the case of Beijing', FinGeo Working Paper No. 10, January, Global Network on Financial Geography, Oxford University. 
Pažitka, V. and Wójcik, D. (2017), 'Cluster dynamics of financial centres in the United Kingdom: do connected firms grow faster?', FinGeo Working Paper No. 4, July, Global Network on Financial Geography, Oxford University.

Rodríguez-Pose, A. (2004), 'On English as a vehicle to preserve geographical diversity', Progress in Human Geography, 28 (1), 1-4.

Rodríguez-Pose, A. (2006), 'Commentary: is there an "Anglo-American" domination in human geography? And, is it bad?', Environment \& Planning A, 38 (4), 603-10.

Roy, A. (2010), Poverty Capital: Microfinance and the Making of Development, London: Routledge.

Vergara Caffarelli, F. and Veronese, G. (2018), 'Costs of Italian economic diplomacy: a comparative perspective', in P. Van Bergeijk and S. Moons (eds), Research Handbook on Economic Diplomacy Bilateral Relations in a Context of Geopolitical Change, Cheltenham, UK and Northampton, MA, USA: Edgar Elgar, pp. 204-19.

Wallerstein, I. (1974), The Modern World-System: Capitalist Agriculture and the Origins of the European World-Economy in the Sixteenth Century, New York: Academic Press.

Wójcik, D. and Cojoianu, T. (2017), 'Unfinished business: change in the US securities industry since 2008', FinGeo Working Paper No. 9, October, Global Network on Financial Geography, Oxford University.

Wójcik, D., Knight, E., O’Neill, P. and Pažitka, V. (2017), 'Investment banking since 2008: geography of shrinkage and shift', FinGeo Working Paper No. 3, March, Global Network on Financial Geography, Oxford University.

Woods, S. (2017), 'Geofinance-speechbySam Woods. Given at the Mansion HouseCity Banquet, London', Bank of England, London, 4 October, accessed 16 July 2019 at https://www.bankofengland.co.uk/speech/2017/geofinance-speech-by-sam-woods.

Yunus, M. (2009), Creating a World without Poverty: Social Business and the Future of Capitalism, New York: Public Affairs. 